\title{
A Study on the Perception of Congolese Students towards Sape
}

\author{
Basile Mulwani Makelele ${ }^{1, *}$, Patrick Litalema Libote ${ }^{2}$, Boniface Aspan A Kasas ${ }^{1}$ \\ ${ }^{1}$ Psychology, The University of Lubumbashi, DR Congo \\ ${ }^{2}$ Psychology, Institut Supérieur Pédagogique de la Gombe, DR Congo \\ *Corresponding author: basilemulwani@yahoo.fr
}

\begin{abstract}
Sape or dandyism is a fashioning behavior which is very popular in some communities of Congolese. Characterized by well dress, beautiful clothes, expensive or designer labels, Sape as psychosocial phenomenon, doesn't have a same perception in student's area. Aims of the Study: The study measures perception of Congolese students towards Sape. Instruments: Questionnaire technique was used to collect data from 64 women and men students aged from 18 up to 40 years old leaving in Kinshasa and Lubumbashi. Results: It emerges from our investigations that Students of Kinshasa (66.6\%) and Lubumbashi (86\%) have a positive perception towards Sape. Conclusion: Fashioning behavior of Sape must be organized in intend of pushing all fanatics of clothes to buy and employ local fashions in state of spending too much money in foreigner designer labels.
\end{abstract}

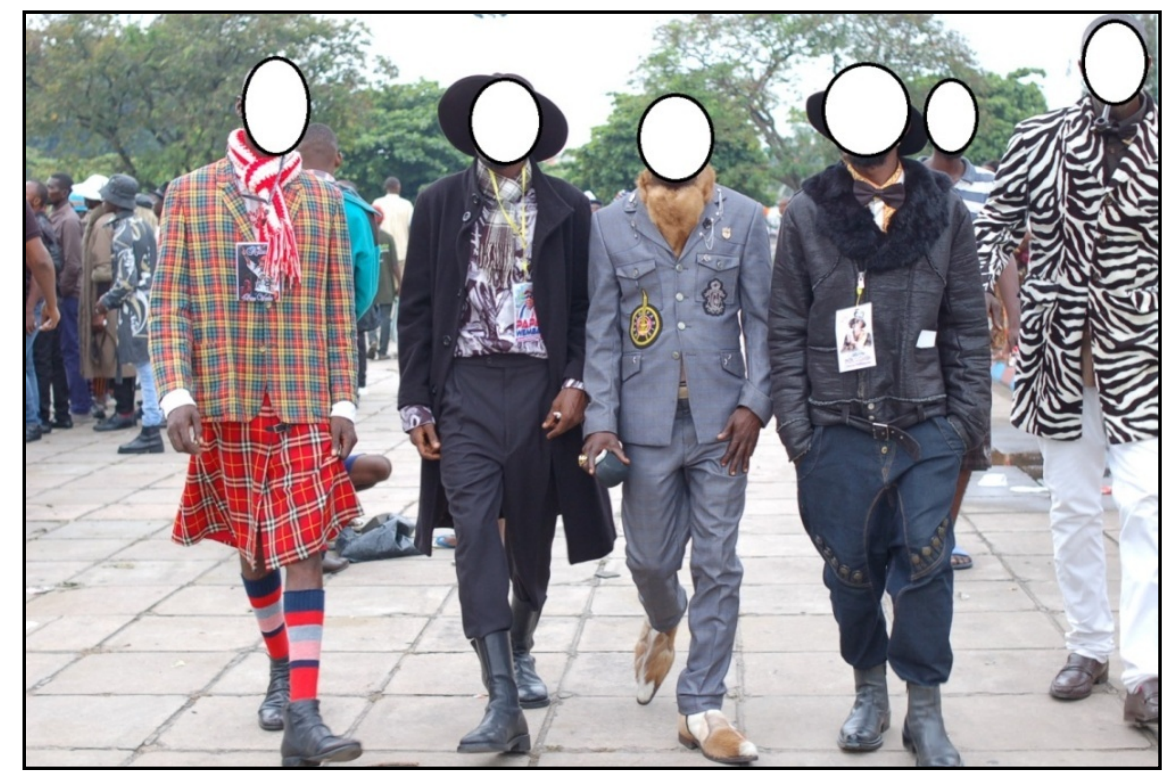

Keywords: Sape, Congolese student, perception, dandyism, fashion behavior

Cite This Article: Basile Mulwani Makelele, Patrick Litalema Libote, and Boniface Aspan A Kasas, "A Study on the Perception of Congolese Students towards Sape." Research in Psychology and Behavioral Sciences, vol. 5, no. 1 (2017): 6-12. doi: 10.12691/rpbs-5-1-2.

\section{Introduction}

\subsection{Design of the Sape}

The Sape was placed in the spotlight of all the media of the whole world after the sudden death of one of its faithful singers, in the person of Papa Wemba ${ }^{l}$.

\footnotetext{
${ }^{1}$ Also nicknamed as: Kuru yaka, Jules Presley, 100\% star, Ekumani Bakala Diakuba, Fulangenge, Formateur des idoles, Mwalimu, Maitre d'école, Vieux Bokul, Mzee, Notre père, Mangrokoto grand prêtre, Kolo histoire, "Rossignol" de la rumba...
}

His real name Jules Shungu Wembadio Pene Kikumba, a musician from Democratic Republic of Congo, Papa Wemba died on Sunday April 242016 at dawn in Abidjan, Côte d'Ivoire, "following a malaise on stage", A "cardiac arrest" or what the medical world refers to as "massive infarction", while singing as a true Sapeur. Declaration of death announcement read by Salif Traoré, General Commissioner of the Festival of Urban Music of Anoumabo [1].

The Sape remains the social object of imitation by a partisan people. It also evokes the harmony in the perception of values, styles or old and current fashions, depending on whether the dress tendency, the Sape leaves 
the impression behind every adept of the well-dressed empire.

Kinshasa Sapeurs are recognized for being much more performed, often using soccer stadiums or street corners for their gatherings while their more conservative Brazzaville counterparts prefer meeting in cafés [2].

The beauty of the Sapeur is found in the choice of cloths, the glitter of glasses and the smoothness of velvet or leather of the Sapeur, but also in the knowledge to dress and synchronize the colors. The price comes after, well after the "good feeling" of the Sapeur and his spectator. The Sapeur feels himself attaining the perfection of his clothing in the admiration which others display by seeing him well-dressed, but also by the self-admiration which the Sapeur dedicates to himself.

It should be pointed out that the Sape is not only clothing, it is also and above all a set of behaviors as much clothing, as gait and conduct in society. One does not recognize a Sapeur solely by his clothing, but also by his gait, his luxurious clothes and by his actions and gestures. Thus, the Sape is not only a fashion, but above all a way of life.

The acronym S.A.P.E. (Société des Ambianceurs et des Personnes Elégantes ${ }^{2}$ ) appears at the beginning of the Seventies. It designates a popular clothing movement that is developing around music, in Brazzaville and Kinshasa, in connection with stays in Europe by Congolese [3].

Though the origins of the movement are of some debate, both in terms of location and impetus, the most cogent trajectory of la Sape's existence unfolds in three phases spanning the last century, beginning surreptitiously in colonial Kinshasa (circa 1950) and changing force and direction during the early 1970 s in the early years of the post-colony before shifting once again in the late 1990s as president Mobutu's political regime began to unravel [2].

Adrien Mombele Samba N'gantshie, known as Strervos Niarcos ${ }^{3}$, is considered to be the Pope of the Kitendi religion (Sape) surely for spreading it through the songs and at the music concerts in the band of Papa Wemba that he used to attend. The latter will testify in particular that Strervos Niarcos was a master and a faithful precursor of the habits and customs of the Sape.

When Strervos Niarcos returned in Kinshasa in 1989, there were motorcyclists who escorted him from the airport to La Voix du Zaïre where he gave his first interview. We have fashion like Jitrois jackets, Issey Miyake pants; Weston shoes [4].

Sapeur is characterized by demonstration processions or "colonization" of others, striking power of his clothes, shoes, belt, socks, hat or headband, glasses, pipe or cane, or even his ring or watch. We recognize a Sapeur from his exhibitions of clothes, his arrangements, and his harmony of cloths.

Clothing behavior is perceived differently by individuals and in terms of their own experience. The art of dressing well, that is the Sape, does not derogate from this principle. Students do not perceive in the same way the phenomenon of Sape, and especially that this mode of clothing did not begin in the student's area.

There is a need to seek the image as the perception of each individual or group of individuals on the Sape:

\footnotetext{
${ }^{2}$ Société des Ambianceurs et des Personnes Elégantes: Society of Tastemakers and Elegant People.

${ }^{3}$ Dubbed as Mukaravia Malela, Eddie Barra, Niarka Kouroubio, Papa na Maty, Gianni Versace, the N'ganthié.
}

fashion clothing, belief or culture of a group of fanatics of the "well dressed".

If previous generations have experienced dandyism, the Sape, like an art and clothing fashion, seduces degree of perception of a particular audience that was completely there, and astonishes another audience that finds this dress behavior strange.

Dandyism is a lifestyle modeled around 1790 by English elites, one of whose pioneers was George Bryan Brummell (1778-1840), alias Beau Brummell [5].

Far from being an unusual phenomenon or an exclusive creation of the inhabitants of Kinshasa and Brazzaville, the Sape is close to the dandyism. Dandyism and Sape have obvious similarities in the actions, such as self-admiration and over-valorization through clothing and gait.

The difference between the Sape and Dandyism lies in the time and place of their manifestation (England-1820 for dandyism and Brazzaville-Kinshasa-1960 for Sape) as well as in the main motivations of their followers (if dandyism was a men behavior wanting to resemble women from the point of view of refined clothing, careful manner and talks in salons, cafeterias or bars, the Sape on the other hand is a quest for over-valorization of young artists wanting to reach higher social class).

\subsection{Literature Review on Sape Studies}

A series of studies on the Sape as a social phenomenon, carried out by sociologists, anthropologists and even stylists, emerged. Our research analyzes the perception of Congolese students towards Sape. It differs from the previous studies by the compressed in lines below.

"Sape as phenomenon" was careful decrypted by Gandoulou [6] in many points like Sapeurs adventure trail; Parisian life of the Sapeurs and their life in the Congo; origins of the Sape movement; political significance of the Sape movement and the role of colonization; Socioanthropological view of the Sape movement.

Reporting on the fashion name "Sape" in the political world of Congo-Brazzaville, Bazanguisa [7] established a link between politics and luxury clothing; attempted to reply to the question "Why does Sape interest the Congo so much"; and analyzed the historical transformations of political structures to show how the Sape is a subculture.

If Gondola [8] studied the Sape and African Sapeurs established in France; also described the cultural itinerary and dreamlike journey of the Sapeurs in Europe. Hanon [3] analyzed the semantic field of Sapeurs living in Brussels in an anthropological study carried out in 2003-2004 in the circles of Congolese immigration in Brussels on a series of words derived from the particular language of the Sape.

Coulibaly, Brodin \& Ladwein [9] expected the representation of luxury in Sapeurs and the identity mechanisms that are involved in the choice of luxury brands and / or designer labels.

\section{Materials and Methods}

\subsection{Description of Study Area}

The students surveyed in our inquiries come from the pedagogy's' high Institute of Gombe, (in acronym: 
ISP/Gombe), in Kinshasa, and from the University of Lubumbashi (UNILU in acronym).

The ISP/ Gombe is located in Kinshasa downtown precisely in the Gombe municipality [10]. It is a public high institution in the Democratic Republic of Congo and organizes 10 departments, including psycho-pedagogy.

UNILU is a public high school institution in the Democratic Republic of Congo. Localize in the city of Lubumbashi, it includes fifteen faculties and schools, counting the Faculty of Psychology and Education Sciences.

Situated at the extremities of the country, in the West and in the South-East, for a distance of about $2000 \mathrm{Km}$ (about 1242,742 miles), the two sites which make up our field of investigation (Kinshasa and Lubumbashi) are the first two Cities of the Democratic Republic of Congo, a country of Central Africa with continental dimensions and the immense potential riches of its soil and subsoil.

Kinshasa and Lubumbashi are culturally and morally threatened cities due to the cultural and traditional mixing of foreign and neighboring cultures.

The city of Lubumbashi, with an area of $747 \mathrm{~km}^{2}$, is an important city of the Democratic Republic of Congo. Originally a mining town, then administrative, it has a tropical two-season climate (dry and rainy).

Kinshasa is largely inhabited by people from all provinces of the DRC and various countries of the world [11]. It is therefore a cosmopolitan city that knows an exponential demography estimated to date to more than twelve million inhabitants.

As the African capital of music, Kinshasa better highlights the expansion and expression of the Sape movement. In almost every one of its twenty-four municipalities, there are distinguished groups of young men who devote themselves to the Sape.

Kinshasa originated from Teke, a local language, Kinshasa means: a little Salt Market (insasa, insa or insainsa). This name became official after the country's independence in 1966, replacing that of Leopoldville, which was given in 1881 by the explorer Henry Morton Stanley in honor of the King of the Belgians, Leopold II, whose service he was.

Lubumbashi is a name originated from Lubumbashi River. That in Lamba, local language, Lubumbashi means: ulubumba (clay). The clay that women used to shape vases and pots (lubumba also means potter producing clay pots). And founded in 1910 by the Belgians under the name of "Elisabethville", the city was renamed Lubumbashi in 1965 .

\subsection{Description of the Study Sample}

To constitute our study sample, we preferred to investigate in two student's circles, one of which is considered to be the bastion of the phenomenon studied that is the Sape (the City of Kinshasa), while the other is a remote medium of this reality (the City of Lubumbashi). And a non-probability sampling design (convenience sample) was used to draw the sample.

Our study sample consists of 64 students, whose characteristics are represented in the Table 1 below by gender (women and men), age (18 up to 40 years old) and survey site (Kinshasa and Lubumbashi).
Table 1. Characteristics of the sample

\begin{tabular}{llcc}
\hline & Variables & Number & Percentage \\
\hline \multirow{2}{*}{ Gender } & Women : & 23 & 35.9 \\
& Men : & 41 & 64.1 \\
\hline \multirow{2}{*}{ Age } & $36-41:$ & 1 & 1.56 \\
& $30-35:$ & 6 & 9.38 \\
& $24-29:$ & 19 & 29.69 \\
& $18-23:$ & 38 & 59.38 \\
Survey site & Kinshasa : & 30 & 46.9 \\
& Lubumbashi & 34 & 53.1 \\
\hline
\end{tabular}

The characteristics of our sample, summarized in the Table 1 above, show for gender, it included $35.94 \%$ of women students and $64.1 \%$ of men students; for age, it had more than half of the respondents aged 18 to 23 $(59.38 \%)$, followed by those aged 24 to 29 (29.69\%); and finally, for survey site, it contained $53.1 \%$ of students from Lubumbashi and $46.9 \%$ from Kinshasa.

\subsection{Technique of Data Collection and Aim of the Study}

We used the questionnaire technique to collect data. But, before administering the questionnaire, we observed a parade of the Sapeurs in front of the court of the Parliament on the eve of the burial of Papa Wemba (musician and leader of Sape). As an inspiration for this study, this observation allowed us to identify, through the public getup, the different categories of Sapeurs.

Thus, the object of this study is the perception that 64 students (aged 18 to 40) of Kinshasa (called Kinois ${ }^{4}$ ) and Lubumbashi (called Lushois ${ }^{5}$ ) have of the Sape and the Sapeurs, as psychosocial phenomenon that takes place in their environment of life.

The aim of this study is to measure the perception of Congolese students about the Sape phenomenon by answering to four open ended questions detailed as follows:

1) What is the understanding of the word Sapeur (dandy)?

2) What motivate someone to be engaged in Sape (dandyism)?

3) What are the methods of acquisition luxury clothes by Sapeurs (dandies)?

4) Who are names of some Sapeurs (dandies) of Kinshasa?

We have applied for three students' promotions at University of Lubumbashi and two promotions at ISP/Gombe in Kinshasa were we administrated our questions.

\section{Results}

In the following section, we expose results (in percentage based on number of responses) regarding participants' notions of Sapeur, on Sape motivations, on Modes of provision of clothing for Sapeur and on Names

\footnotetext{
${ }^{4}$ Kinois: inhabitant of Kinshasa

${ }^{5}$ Lushois: inhabitant of Lubumbashi
} 
of some Sapeurs of Congo. Additionally, we present the perception view concerning hitch table of the results which can be positive, negative or neutral.

\subsection{Sapeur Notions}

Results regarding participants' notions of Sapeur are summarized in Table 2 below, categorized by their level of perception.

The Table 2 shows that the notion of the word fashion named "Sape" differs among the subjects questioned. There are three perceptions (per percentages of choices) that motivate any Sapeur: positive perception, negative perception and neutral perception.

As positive perception towards Sape, for Kinshasa students, a Sapeur is a person who "likes to dress well" (25.6\%); who puts on "beautiful, expensive or designer labels clothes" (17.9\%); who "Knows how to dress and synchronize colors" $(7.7 \%)$; who is "showing off his clothes" $(7.7 \%)$; "having a lot or plenty of clothes" $(5.1 \%)$ and who like "being clean" (2.6\%). For Lubumbashi students, positive perception towards Sape are who "likes to dress well" $(47.2 \%)$; who puts on "beautiful, expensive or designer labels clothes" (16.7\%); who "Knows how to dress and synchronize colors" (13.9\%); who like "being clean" (5.6\%); who is "showing off his clothes" $(2.8 \%)$; "having a lot or plenty of clothes" $(2.8 \%)$.
As negative perception towards Sape, $7.7 \%$ of Kinshasa students consider it in "bizarre clothes, exaggerated and strange".

\subsection{Sape Motivations}

Results regarding participants' responses on Sape motivations are summarized in Table 3 below, ordered by their level of perception.

The Table 3 shows that according to the students of Kinshasa and Lubumbashi, there are three perceptions (per percentages of choices) that motivate any Sapeur: positive perception, negative perception and neutral perception.

As positive perception towards Sape for Kinshasa students, motivations of Sapeur are "to be admired", to be a star" or by "passion" (11.8\%); "dressing well and loving clothes" $(8.8 \%)$. and "to promote oneself" $(2.9 \%)$. And for Lubumbashi students, motivations of Sapeur are "to promote oneself" (20\%); "to be admired" (17.1\%); "to be a star" $(8.6 \%)$ and by "passion" $(2.9 \%)$ or "dressing well and loving clothes" (2.9\%).

As negative perception towards Sape motivations, Kinshasa students consider Lack of occupation (unemployed) (8.8\%); To display one's wealth $(5.9 \%)$; Lack of good education $(2.9 \%)$; To convince oneself of having a lot of clothes $(2.9 \%)$ and Want to complement in what one lacks $(2.9 \%)$. when Lubumbashi students consider only to display one's wealth (14.3\%) and Pride/ arrogance (11.4\%).

Table 2. Analysis of the notions about the Sape

\begin{tabular}{|c|c|c|c|}
\hline Perception & Notions & Kinshasa \% & Lubumbashi \% \\
\hline \multirow{6}{*}{ Positive (66.6 Vs 86\%) } & Likes to dress well & 25.6 & 47.2 \\
\hline & Beautiful clothes, expensive or designer labels & 17.9 & 16.7 \\
\hline & Knows how to dress and synchronize colors & 7.7 & 13.9 \\
\hline & Show his clothes & 7.7 & 2.8 \\
\hline & Plenty of clothes & 5.1 & 2.8 \\
\hline & Clean & 2.6 & 5.6 \\
\hline Negative $(7.7 \%)$ & Bizarre clothes, Exaggerated, Strange & 7.7 & 0.0 \\
\hline \multirow{4}{*}{ Neutral (25.6 Vs $11.2 \%)$} & Different from others & 5.1 & 5.6 \\
\hline & Talk about clothes & 5.1 & 2.8 \\
\hline & Imitate clothing of others & 5.1 & 0.0 \\
\hline & Others (Employee at the Sape, Humorous clothes) & 10.3 & 2.8 \\
\hline
\end{tabular}

Table 3. Analysis of motivations that drive someone to engage in the Sape

\begin{tabular}{|c|c|c|c|}
\hline Perception & Motivations & Kinshasa \% & Lubumbashi \% \\
\hline \multirow{6}{*}{ Positive (53Vs 51.5\%) } & To be admired & 11.8 & 17.1 \\
\hline & To promote oneself & 2.9 & 20 \\
\hline & To be a star & 11.8 & 8.6 \\
\hline & Passion & 11.8 & 2.9 \\
\hline & Dressing well and loving clothes & 8.8 & 2.9 \\
\hline & Taste of cleanliness & 5.9 & 0.0 \\
\hline \multirow{6}{*}{ Negative (23.4Vs $25.7 \%)$} & To display one's wealth & 5.9 & 14.3 \\
\hline & Pride/ arrogance & 0.0 & 11.4 \\
\hline & Lack of occupation (unemployed) & 8.8 & 0.0 \\
\hline & Lack of good education & 2.9 & 0.0 \\
\hline & To convince oneself of having a lot of clothes & 2.9 & 0.0 \\
\hline & Want to complement in what one lacks & 2.9 & 0.0 \\
\hline \multirow{2}{*}{ Neutral (23.5Vs 22.8\%) } & Influence or imitation & 20.6 & 17.1 \\
\hline & At the sight at designer labels or fashion & 2.9 & 5.7 \\
\hline
\end{tabular}




\subsection{Modes of Provision of Clothing for Sapeurs}

Results regarding participants' responses on Modes of provision of clothing for Sapeurs are summarized in Table 4 below, structured by their level of perception.

The simple view of the Table 4 reveals that the students estimate that the way of obtaining the clothes by the Sapeurs are, as positive perception, the purchase (60\% for Lubumbashi and 55.2\% for Kinshasa), the donation (31\% for Kinshasa and $15.6 \%$ for Lubumbashi) and borrowing (13.8\% for Kinshasa and 6.7\% for Lubumbashi).

As negative perception, the way of obtaining the clothes of the Sapeurs are "Theft, swindling" for 11.1\% Lubumbashi students.

The students of Kinshasa put forward three means that the Sapeurs use to have clothes: the purchase, the donation and the borrowing. Students in Lubumbashi distinguish more than these three means, including, theft or swindling.

\subsection{Names of Some Sapeurs of Congo}

Results regarding participants' responses on Names of some Sapeurs of Congo are summarized in Table 5 below, structured by their occupation of the subject cited as Sapeur.

The perception of the Sapeurs is different among the students of Kinshasa and those of Lubumbashi. Kinshasa students cited 16 authentic Sapeurs like Papa Wemba (30.2\%), Emeneya (20.8\%), Stervos Niarcos (9.43\%), Papa Griffes (7.55\%), Ayi Gola (5.66\%), Kabos de Boss (3.77\%), Grand maitre, Jacos, Kendjo, Mama Griffes, Munze, Persino Bilele, Pitchienne, Sida Bilele, Vieux Djo and Zara (1.89\%). But Lubumbashi students cited 5 authentic sapeurs like Papa Wemba (29.5\%), Emeneya (6.41\%), Stervos Niarcos, Papa Griffes and Equilibre (1.28\%).

Table 4. Analysis of procuration modes of clothing by Sapeurs

\begin{tabular}{|c|c|c|c|}
\hline Perception & Modes & Kinshasa \% & Lubumbashi \% \\
\hline \multirow{3}{*}{ Positive (100 Vs $82.3 \%$ ) } & Purchase & 55.2 & 60 \\
\hline & Donation & 31 & 15.6 \\
\hline & Borrowing & 13.8 & 6.7 \\
\hline Negative (11.1\%) & Theft, swindling & 0.0 & 11.1 \\
\hline Neutral $(6.7 \%)$ & Other (by any resource) & 0.0 & 6.7 \\
\hline
\end{tabular}

Table 5. Analysis of the names of some Sapeurs of Congo

\begin{tabular}{|c|c|c|c|}
\hline Occupations & Names of Sapeurs & Kinshasa \% & Lubumbashi \% \\
\hline \multirow{3}{*}{ Dandy and Musician (60.43Vs 37.19\%) } & Papa Wemba & 30.2 & 29.5 \\
\hline & Emeneya & 20.8 & 6.41 \\
\hline & Stervos Niarcos & 9.43 & 1.28 \\
\hline Dandy and shoes manufacturer (7.55Vs $1.28 \%)$ & Papa Griffes & 7.55 & 1.28 \\
\hline \multirow{13}{*}{ Dandy (28.33Vs 1.28\%) } & Ayi Gola & 5.66 & 0 \\
\hline & Kabos de Boss & 3.77 & 0 \\
\hline & Equilibre & 0 & 1.28 \\
\hline & Grand maitre & 1.89 & 0 \\
\hline & $\mathrm{Jacos}$ & 1.89 & 0 \\
\hline & Kendjo & 1.89 & 0 \\
\hline & Mama Griffes & 1.89 & 0 \\
\hline & Munze & 1.89 & 0 \\
\hline & Persino Bilele & 1.89 & 0 \\
\hline & Pitchienne & 1.89 & 0 \\
\hline & Sida Bilele & 1.89 & 0 \\
\hline & Vieux Djo & 1.89 & 0 \\
\hline & Zara & 1.89 & 0 \\
\hline \multirow{14}{*}{ Musician (3.78Vs 60.43\%) } & Koffi olomide & 1.89 & 17.9 \\
\hline & Fally Ipupa & 1.89 & 12.8 \\
\hline & JB Mpiana & 0 & 7.69 \\
\hline & Werrason & 0 & 7.69 \\
\hline & Ferre Gola & 0 & 2.56 \\
\hline & Barbara Kanam & 0 & 1.28 \\
\hline & Blaise Bula & 0 & 1.28 \\
\hline & Defao & 0 & 1.28 \\
\hline & Fabregas & 0 & 1.28 \\
\hline & Karmapa & 0 & 1.28 \\
\hline & Manseba & 0 & 1.28 \\
\hline & MJ 30 & 0 & 1.28 \\
\hline & Tabuley & 0 & 1.28 \\
\hline & Wezekwa & 0 & 1.28 \\
\hline
\end{tabular}




\section{Discussion}

We recall that our result fixed for a majority students of Kinshasa $(66.6 \%)$ and Lubumbashi $(86 \%)$ to have a positive perception towards Sape.

Before discuss about this perception towards Sape, we must note that psychological variables (attitude, perception, self-concept, personality and motivation) are significant predictors of fashion consumption behavior [12]. But social stereotypes are a special case of interpersonal perception and may guide and influence the perceiver's interactions with the target [13].

Also, let underline that people judge each other on first impressions [14] and dressing is considered as the factor for representing the social status of the person [15], that way clothing reflects the values, attitudes and interests of the wearer $[16,17,18]$.

As for wearing strange, exaggerated or strange clothing, forms of clothing, colors and eccentricities make it an originality and provide clothes (kitendi) with an extraordinary power, a supernatural force that transcends the understanding of the spectators and gives the wearer (Sapeur) a sensation of a superman, of differentiation, of reincarnation in a new creature endowed with a power of domination, overtaking, exaltation and victory: that is what the Sapeur calls colonization.

Moreover, we recall that motivations of Sapeur cited are "to be admired", "to be a star", "to promote oneself", by "passion" and "dressing well and loving clothes"; other than their ways to get clothes are purchase, donation and borrowing.

The obsession with clothing is reflected in the Sapeur by a passion for always dressing well and better. It even becomes his religion; he believes in clothes, kitendi, and devotes all his energies and financial resources to dress.

Passion is also one of the clear reasons that would easily explain the actions of the Sapeurs. A Sapeur is always passionate about his art; it is a second nature for him. The Sape is, for him, a euphoric substance (or a drug) that plunges him into a second state, which gives him a feeling of gaiety, total and complete sufficiency.

The Sapeur claims to hover over others, dominate his self-esteem and achieve a level of satisfaction that is remarkable for his smile, enlightened gaze, and mental or psychic exuberance of fullness whenever he spreads his "well-good and better-dress".

Many of the Sapeurs receive clothing donations from their acquaintances that live in the West and buy clothes for them, especially during promotion periods (ranging from $30 \%, 50 \%$ or even $70 \%$ ) in luxury clothing boutiques. Other Sapeurs still, especially those who go around musicians, receive donations of clothes from their idol or protector musicians, who are models, dressed in haute couture houses.

Though expensive and overpriced, the luxury clothes of the Sapeurs are bought after harsh sacrifices. It is this symbolism of possessing objects of great value that accentuates megalomania in the Sapeur. He will say that he is reigning by displaying his clothing trophies like a cup conquered on enemy lands.

This endowment of luxury clothes increases the feeling of recognition of Sapeurs towards their mentor "mikilists"
(Congolese diaspora living in the West most often) or high priests musicians.

A sapeur devotes his money and life to dress himself with expensive and elegant brand clothes from West cities and to display them ostentatiously in public [19].

Another kind of Sapeurs borrows clothes from relatives, for a rental fee. They rent these clothes for 24 to 48 hours; put them to show themselves in front of a known or unknown public in order to satisfy so little their ego bruised by the conditions in which they live.

In the case of loans, certain Sapeurs collaborate with clothing shops and serve as street models who wear clothes for a few hours, to inform the interested public about the product ranges they display and places where they "buy" them.

Indeed, a Sapeur will often wear clothes, without removing the labels, in order to address all those who want to buy these kinds of clothes, and well-sapped as is the one who carries them.

Finally, the Sapeurs receive donations of clothes from various people, whom they affectionately call great donors Preso, Mopao, Fulangenge.

We will add another mode of procuring clothes: personal creation. Some Sapeurs themselves make the clothes they wear because they are couturiers. Still others, themselves make the shoes they put on, for they are great shoemakers. This is the case of Papa Griffes, a creator of shoes that he wears or makes available to other Sapeurs who reign at the Sape competitions held in Kinshasa.

However, about names of Sapeurs, the perception is different among the students of Kinshasa and those of Lubumbashi. Coutant [20] inform us that Papa Wemba \& Emeneya are the pivot of the great Sapeurs of Kinshasa. Going in the same way, we discover that Kinshasa students put Papa Wemba (30.2\%), Emeneya (20.8\%) and Stervos Niarcos $(9.43 \%)$ at the head of the list. When Lubumbashi students cited more only Papa Wemba (29.5\%), following by some musicians like Koffi olomide (17.9\%), Fally Ipupa (12.8\%), JB Mpiana (7.69\%), Werrason (7.69\%). Emeneya (6.41\%) and Stervos Niarcos $(1.28 \%)$ are at the foot of the list.

African fashion industry is emerging in Africa as many talented designers and investors make their ways, like young fashion designers of Nigeria, Ghana, Cameroun, Senegal and Burkina Faso are growing continuously ranging from haute couture to streetwear [19,12-21].

\section{Conclusion}

Papa Wemba, Emeneya or Stervos Niarcos, Papa griffes, Mama africa, Bilele, Tekasala, El chanto, Didier Mwanza, Colonel Jika and Maman clémentine are Sapeurs. But, who is Sapeur?

Sapeur is a person who "likes and knows dress well", puts on "beautiful, expensive or designer labels clothes", and "showing off his clothes". He is motivated by "admiration of others and promotion of himself" to satisfy his ego.

The means or modes used to obtain clothing vary from one Sapeur to another. They buy, receive donations or borrow. Some category of Sapeurs even uses the theft of 
clothes, fraud or prostitution when other category exchange clothes between them or with no-Sapeurs.

However, the Lushois also consider that the Sapeurs resort to robbery or swindling to get the luxury clothes they put on. For a Lushois, it is inconceivable that a person who has difficulty can dispose of trunks full of luxurious clothes (doubtless suspicious), whereas for the Kinois nothing is impossible (chance eloko pamba ${ }^{6}$ ).

The Sapeur will no longer be content to dress well in luxurious garments and in harmony of color and form. But, he will also be a model, a popular star, a star that everyone grumbles. And much more, the Sapeurs create their own clothing. They no longer content themselves with luxurious clothes, but can buy clothes in second-hand stores and modify them as they wish.

Fashioning behavior of Sape must be organized in intend of pushing all fanatics of clothes to buy and employ local fashions in state of spending too much money in foreigner products.

\section{References}

[1] Kouadio, I. "Le Femua endeuillé par la mort de Papa Wemba". s.l. : www.rfimusique.com, 2016

[2] Jorgensen, K.E. "Sapologie:Performing Postcolonial Identity in the Democratic Repuplic of Congo". Toronto, Ontario : Master of Arts Contemporary Art, Design and New Media Histories, 2014

[3] Hanon, T. Lexique de la Sape : un outil construit dans le cadre d'une étude anthropologique. Bruxelles : ULB, 2004.

[4] Delhaye, E. "Le Pape de la Sape". s.1. : Society-magazine.fr, 2015.

[5] Casden. "Le Dandysme dans la littérature". s.l. : www.casden.fr, 2016.

[6] Gandoulou, J.D. Entre Paris et Bacongo. Paris : Centre Georges Pompidou, Centre de création industrielle, 1984.

[7] Bazanguisa, R. "La Sape et la politique au Congo". s.1. : In Journal des Africanistes. Tome 62, Fascicule 1, 1992. pp. 151-157. Vol. tome 62 .
[8] Gondola, D. "La Sape des mikilistes: théâtre de l'artifice et représentation onirique". s.l. : In Cahier d'études africaines, Vol.39, n¹53, pp.13-47, 1999. pp. 13-47.

[9] Coulibaly, D., Brodin, O. et Ladwein, R. "Marques de luxe, logique identitaire, contrefaçon et risque de bonnissement communautaire: le cas des Sapeurs noirs africains". Genève : Colloque International Luxe et Contrefaçon, 2011.

[10] ISP/Gombe. Création et mission de l'ISP/Gombe. s.l. : www.ispgombe.net, 2016

[11] Mbuangi. Monographie de la ville de Kinshasa. Kinshasa: Ministère du Plan, RDC

[12] Agu, A.G. and Onuoba, O.A. "Psychological Influences ans Fashion Consumption Behaviour of consumers in South East Nigeria". s.1.: International Journal of Reasearch in Business Studies and Management, Vol.3, Issue 123, pp.38-48, 2016.

[13] Snyder, M., Tanke, E.D. and Berscheid, E. "Social Perception and International Behavior:On the Self-Fulfilling Nature of Social Stereotypes". s.1. : Journal of Personnality and Social Psychologiy, Vol.35, Nº9, pp.655-666, 1997.

[14] Mcdermott, L.A. and Pettijohn II, T.F. "The influence of clothing fashion and race on the perceived socioeconomic status and person perception of college students". s.l. : Psychology and Society, Vol.4, N², pp.64-75, 2011

[15] Hasan, S.A., Subhani, M.I. and Osman, A. "New Article of Clothinf translate th Mood of an Individual". s.l.: Munich Personal RePEc Archive, Paper $N^{\circ} 34761,2011$.

[16] Ofori, I. Mesah, A., Amenakpor, F. and Gablah, P.G. "Perception of University of Ghana students towards Campus Female Fashion". s.1. : Arts and Design Studies, Vol.25, 2014.

[17] Twigg, J. "Clothing, age and the body: a critical review". s.1. : Ageing and Society, $\mathrm{N}^{\circ} 27$, Cambridge University Press, pp. 285-305, 2007.

[18] Hokkanen, S. "Fashion brands and consumption in postmodern consumer culture. The construction of self and social identities". s.l. : Degree of Master in Textile Management, Swedish School of textiles, University of Boras, 2014.

[19] Oberhofer, M.A. "Fashioning Africa Cities: The Case of Johannesburg, Lagos and Douala". s.1.: Streetnotes, $\mathrm{N}^{\circ} 20$, pp. $65-89,2012$

[20] Coutant. "Le Phenomène de la Sape au Congo". Groupe d'étude et de recherche sur la mode (GEMode). s.1. : www.gemode.org, 2009

[21] Langevang, T. "Fashioning the future : Entrepreneuring in Africa's emerging fashion industry". s.l. : Working Paper,N²5, 2016.

\footnotetext{
${ }^{6}$ Chance eloko pamba: a Lingala statement (Bantu language spoken in Kinshasa) which justifies acquisition of the goods or accession to a position below his capacities and means. In other words, "luck belongs to everyone ..."
} 